\title{
Variations in Opioid Responsiveness
}

From: Albany Medical College, Albany, NY.

Dr. Smith is Associate Professor and Academic Director of

Pain Management for Albany Medical College Department of Anesthesiology, Albany, NY.

Address correspondence: Howard S. Smith, MD

Associate Professor \& Academic Director of Pain Management Albany Medical College Department of Anesthesiology 47 New Scotland Avenue; MC-131 Albany, New York 12208

E-mail: smithh@mail.amc.edu

Disclaimer: There was no external funding in the preparation of this manuscript.

Conflict of interest: None.

Manuscript received: 12/03/2007 Revised manuscript received: $01 / 20 / 08$ Accepted for publication: 01/28/2008

Free full manuscript: www.painphysicianjournal.com
It has been appreciated for some time now that humans react differently to opioids. A specific opioid such as morphine sulfate may have specific analgesic effects for certain patients with postherpetic neuralgia whereas in other patients with postherpetic neuralgia, it may provide quite different analgesic qualities. Also, in any one individual patient a particular opioid may provide better analgesia than other opioids. Furthermore, these differences are not unique to analgesia; they can also be seen with other opioid effects/ toxicities. Though many of the differences can be classified neatly into pharmacokinetic and pharmacodynamic differences, there are certain differences which still remain incompletely understood. Also, clinicians are not yet able to easily predict which patients will respond well or poorly to various opioids. As research unravels the various genetics, biochemical, and receptor interaction differences of opioids in humans, it is hoped that easily obtainable, cost-effective testing will become available to aid clinicians in choosing an optimal opioid analgesic for an individual patient, a process which is currently accomplished via health care provider judgment along with trial and error. In the future, knowledge gained from databases on knockout rodents, pharmacogenetics, and gene polymorphisms may impact on the ability of clinicians to predict patient responses to doses of specific opioids in efforts to individualize optimal opioid analgesic therapy. It is conceivable that eventually information of this type may translate into improved patient care. In the future, armed with data of this type, clinicians may become quite adept at tailoring appropriate opioid therapy as well as optimal opioid rotation strategies.

Key words: Opioids, pain, analgesic responsiveness, OPRM1 118G, muopioid receptor, gene polymorphism

Pain Physician 2008; 11:237-248

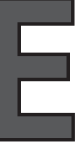

ach patient may respond differently to specific different opioids. There still exists a need to sort out the multiple explanations for some of the variability encountered with the human responses to opioids. The minimal effective analgesic concentration of opioids required for satisfactory analgesia may vary considerably among patients (1, 2). Many factors have been proposed to contribute to these differences in opioid responsiveness including environmental, psychological, and genetic. Emerging research suggests that the allelic variants in the genes involving the opioid (UGT2B7, OPRM1, and ABCB1 genes) and nonopioid systems (COMT gene) may affect the efficacy of morphine in humans. Evidence in animals and humans is accumulating to suggest that some drug-metabolizing enzymes and transporters (including cytochrome P450 [CYP], uridine 5'diphosphate [UDP]-glucuronosyltransferases [UGT], and adenosine triphosphate (ATP)-binding cassette $[A B C]$ transporters) may play a significant role in opioid metabolism as well as influencing the flux of opioids into and out of various sites of opioid target sites (OTS) (Figs. 1 \& 2). These processes appear to have the potential to significantly affect interindividual differences in opioid concentrations in the human body and brain. 

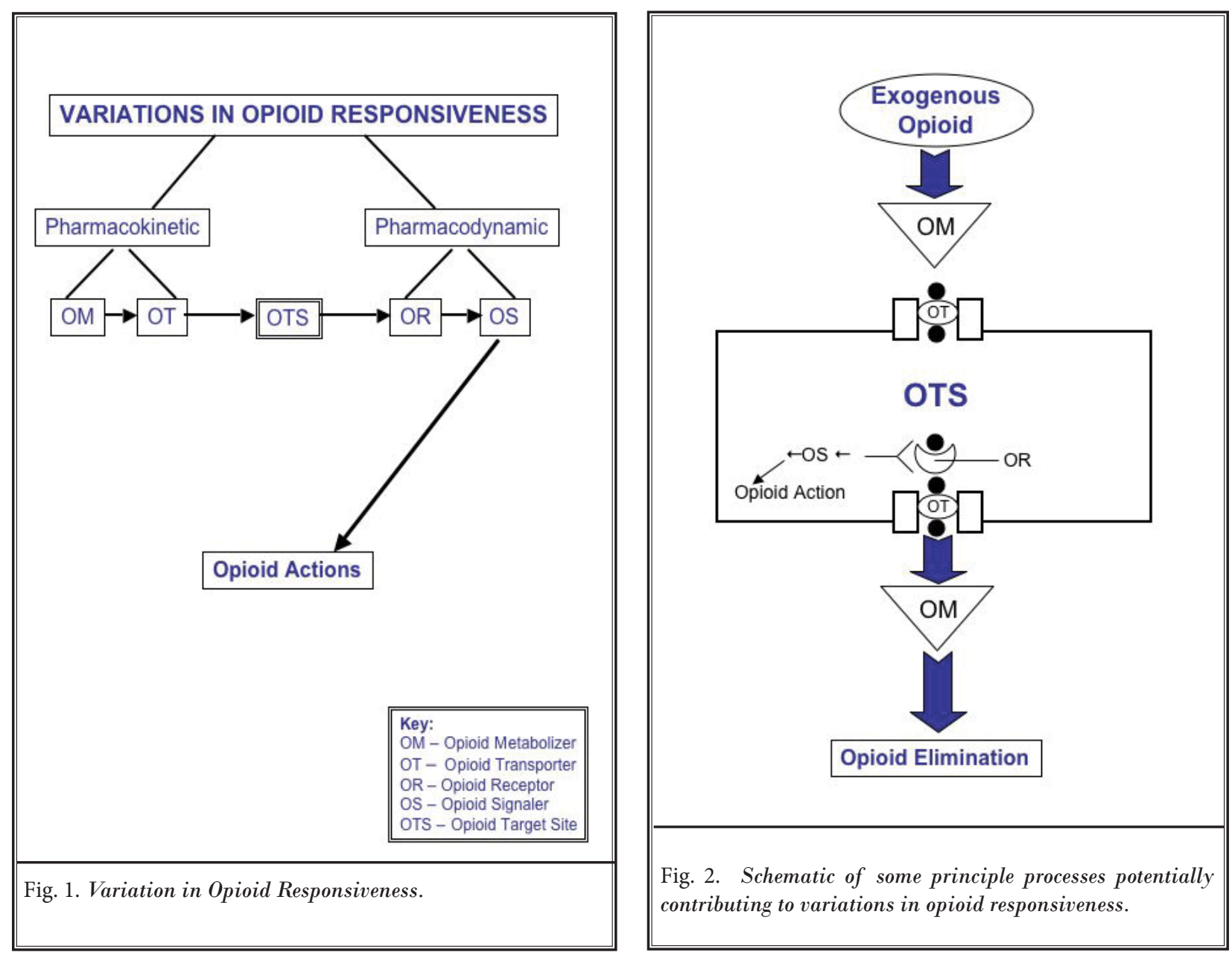

\section{Supraspinal Variability of Opioid Analgesic Actions}

Jones et al (3) compared opioid receptor binding in patients with central post-stroke pain (CPSP) to agematched pain-free control subjects. The reductions in opioid receptor binding within the medial system were observed mainly in the dorsolateral (Brodman area 10) and anterior cingulate (Brodman area 24 with some extension into area 23) and insula cortices and the thalamus. There were also reductions in the lateral pain system within the inferior parietal cortex (Brodman area 40). These changes in binding could not be accounted for by the cerebral lesions shown by CT or MRI, which were outside the areas of reduced binding and the human pain system (3). Jones and colleagues (3) systematically demonstrated a reduction in opioid receptor-binding capacity in neurons within the hu- man nociceptive system in patients with CPSP. Jones et al (3) suggested that these findings may explain why certain patients with CPSP require high doses of synthetic opiates to achieve optimum analgesia.

Maarrawi et al (4) used positron emission tomography (PET) and $\left[{ }^{11} \mathrm{C}\right]$ diprenorphine to compare the in vivo distribution abnormalities of brain opioid receptors (OR) in patients with peripheral and central post-stroke pain (CPSP), matched for intensity and duration. In CPSP patients, interhemispheric comparison demonstrated a significant decrease in opioid binding in the posterior midbrain, medial thalamus, and the insular, temporal, and prefrontal cortices contralateral to the painful side. Peripheral neuropathic pain (NP) patients did not show any lateralised decrease in 
opioid binding. Direct comparison between the central and peripheral groups confirmed a significant OR decrease in CPSP, contralateral to pain (4). While the bilateral OR binding decrease in both CPSP and peripheral NP groups may reflect endogenous opioid release secondary to chronic pain, patients with the more important and more significant lateralized OR decrease (seen contralateral to pain) specific to CPSP suggests opioid receptor loss or inactivation in receptor-bearing neurons (4). Opioid binding decrease was much more extensive than brain anatomical lesions, and was not co-localized with them. Thus, metabolic depression/inactivation (diaschisis) and/or degeneration/loss of opioid receptor bearing neurons secondary to central post-stroke insult appears to be a plausible explanation (4). Central and peripheral forms of NP may differ in distribution of brain opioid system changes and this in turn might underlie their different sensitivity to opiates (4).

Narita et al (5) have provided data which indicate that chronic pain has an anxiogenic effect in mice and this phenomenon may be associated with changes in opioidergic function in the amygdala.

Additionally, the muopioid receptor may couple to voltage-dependent $\mathrm{K}^{+}$conductance in GABAergic terminal through the PLA $/$ arachidonic acid/12-lipoxygenase cascade system (6), and thus, inhibitors of cyclooxygenase and/or 5-lipoxygenase may potentiate opioid analgesia via inhibition of GABA-mediated neurotransmission in rostral ventromedial medulla neurons (7). This may be yet another factor which may help explain the significant variability in human responses to opioids which may be seen.

de Cid et al (8) presented preliminary findings that genetic variability in the brain derived neurotrophic factor (BDNF) signaling pathways may correlate with responses to opioid therapy. de Cid et al (8) analyzed 21 single nucleotide polymorphisms (SNPs). Carriers of the CCGCCG haplotype had an increased risk of poorer response, even after adjusting for Cooperativeness score (OR $=20.2595 \% \mathrm{Cl}[1.46-280.50], P=0.025)$.

Oertel et al (9) investigated the effects of different alfentanil plasma concentration levels (O, $19.6 \pm$ $2.7,47.2 \pm 7.6$, and $76.6 \pm 11.3 \mathrm{ng} / \mathrm{ml}$ ) on pain-related brain activation achieved by short pulses of gaseous $\mathrm{CO}(2)$ delivered to the nasal mucosa, using functional magnetic resonance imaging (fMRI) on a $3.0 \mathrm{~T}$ MRI scanner in 16 non-carriers and 9 homozygous carriers of the muopioid receptor gene variant OPRM1 $118 \mathrm{~A}>\mathrm{G}$. Increasing opioid concentrations has differ- ential effects in brain regions processing the sensory and affective dimensions of pain (9). In brain regions associated with the processing of the sensory intensity of pain (primary and secondary somatosensory cortices, posterior insular cortex), activation decreased linearly in relation to alfentanil concentrations, which was significantly less pronounced in OPRM1 $118 \mathrm{G}$ carriers (9). In contrast, in brain regions known to process the affective dimension of pain (parahippocampal gyrus, amygdala, anterior insula), pain-related activation disappeared at the lowest alfentanil dose, without genotype advance (9).

Furthermore, recently, support has emerged for the theory that a cytochrome P-450 pathway may be involved in supraspinal opioid analgesic signaling that has come from the substance 4(5)- ((4-iodobenzyl) thiomethyl)-1H-imidazole (named CC12) which inhibits some forms of cytochrome P-450 (unpublished observations Hough et al (10)) and possesses anti-analgesic actions. CC12 was found to inhibit opioid, cannabinoid, and improgan antinociception (10).

\section{Spinal Variability of Opioid Analgesic Actions}

Many factors may influence the spinal analgesic efficacy of opioids at opioid receptors in the dorsal horn of the spinal cord. In addition to the state of activity of the descending facilitative and descending inhibitory pathways, the activity of interneurons as well as the pre-existing tone of GABAergic, noradrenergic, serotonergic, and other neural pathways may play a role. Also, the concentration and function of peptides which have been associated with "anti-opioid" properties may potentially contribute to altered opioid analgesia (e.g. Neuropeptide FF [NPFF], cholecystokinin [CCK], melanocyte inhibiting factor [MIF]-related peptides).

\section{Peripheral Variability of Opioid Analgesic Actions}

Multiple factors may contribute to variations of the peripheral analgesic efficacy of opioids at opioid receptors in the periphery. Although it is uncertain which factors are the most important, factors which diminish the number or impede the journey of opioidcontaining leukocytes to the peripheral site of insult may play a key role. Additionally, the pre-existing state or tone of the kinin system, endocannabinoid system, and keratinocytes may contribute in part to variations seen in peripheral opioid analgesia. 


\section{Pharmacokinetic Variability}

\section{Opioid Metabolizers (OMs)}

Considerable evidence is accumulating to suggest genetic variability between individuals and in their ability to metabolize and respond to drugs. All opioid drugs are substantially metabolized, mainly by the cytochtome P450 system and to a lesser extent by UDP-glucuronosyltransferases (UGTs), which are also involved in secondary metabolic pathways. Codeine may be ineffective as an analgesic in about $10 \%$ of the Caucasian population due to genetic polymorphisms in the enzyme CYP2D6 necessary to O-methylate codeine to morphine, the active metabolite. Other polymorphisms can lead to enhanced metabolism and thus increased sensitivity to codeine's effects (11). Genetic variability in the expression or density of opioid receptors, receptor affinity, or secondary messenger activation may explain the interindividual variation seen in patients' responses to morphine. Similarly, variability in the expression of the enzymes responsible for the metabolism of different opioids may contribute to differences in dose requirements and toxicity. In the future, pharmacogenetic mapping may allow us to predict which opioid will be best suited to a particular individual (12).

Approximately $5-10 \%$ of Caucasian populations in Europe and North America lack the functional action of the CYP2D6 enzyme due to inactive mutations in both alleles of the CYP2D6 gene, and they are poor metabolizers (PMs) of debrisoquine and numerous other drugs $(13,14)$. The CYP2D6 gene is highly polymorphic, with 100 allelic variants identified (15). Of these, *3-*8 are nonfunctional, *9, *10, and *41 have reduced function, and $* 1, * 2, * 35$, and $* 41$ can be duplicated resulting in greatly increased expression of functional CYP2D6. There are large interethnic differences in the frequencies of these variant alleles (16). The allele frequency of CYP2D6*10 was found to be $52.4 \%$ in a Chinese population (17). Patients were categorized into 3 groups according to the CYP2D6 genotype: patients without CYP2D6*10 (group I, n = 17), patients heterozygous for CYP2D6*10 (group II, $\mathrm{n}=26$ ), and patients homozygous for CYP2D6*10 (group III, $\mathrm{n}=20$ ) (17). The demographic data among the 3 groups were comparable. The total consumption of postoperative tramadol for $48 \mathrm{~h}$ in Chinese patients recovering from major abdominal surgery in group III was significantly higher then that in groups I and II (17). Allele combinations determine CYP2D6 phenotype: 2 non-functional alleles $\Rightarrow$ poor metabo- lizer (PM) status; at least 1 reduced functional allele $\Rightarrow$ intermediate metabolizer (IM) status; at least 1 functional allele $\Rightarrow$ extensive metabolizer (EM) status; multiple copies of a functional allele and/or allele with promoter mutation (18) $\Rightarrow$ ultrarapid metabolizer (UM) status. CYP2D6 activity is highly variable in EMs and distributed with differences as much as 10,000fold among individuals (19). CYP2D6 also catalyzes the conversion of dihydrocodeine, hydrocodone, oxycodone, and tramadol to dihydromorphine, hydromorphone, oxymorphone, and tramadol metabolite $\mathrm{M} 1$, respectively (20-23). The metabolic clearance of $10 \mathrm{mg}$ hydrocodone to hydromorphone was 8 times faster in EMs $(28 \pm 10.3 \mathrm{ml} \mathrm{h}-1 \mathrm{~kg}-1)$ than in PMs $(3.4 \pm 2.4 \mathrm{ml}$ $\mathrm{h}-1 \mathrm{~kg}-1)$. Furthermore, pretreatment with quinidine, a selective CYP2D6 inhibitor, in the EMs reduced their clearance to levels similar to those in PMs $(5.0 \pm 3.6$ $\mathrm{ml} \mathrm{h-1} \mathrm{kg-1),} \mathrm{and} \mathrm{the} \mathrm{maximal} \mathrm{plasma} \mathrm{concentration}$ for hydromorphone was 5 times higher in EMs than in PMs or in EMs pretreated with quinidine (20). Genetic causes may also trigger or modify drug interactions, which in turn can alter the clinical response to opioid therapy. Due to inhibition of CYP2D6, paroxetine increases the steady-state plasma concentrations of (R)methadone in extensive but not in poor metabolizers of debrisoquine/sparteine (24). In addition to CYP2D6, CYP2B6, 2C19, 3A4, and 3A5 isoforms also are involved in opioid metabolism.

The differences in codeine metabolism between EMs and PMs have been shown to have an impact on patient-controlled analgesia such that a PM received more frequent codeine dosing before leaving the study because of inadequate analgesia compared with the EM group (25). In a study in palliative care patients who were switched from morphine to oxycodone for delirium, the single PM in the group of 12 required the highest dose of oxycodone, had the poorest pain control, and required the greatest number of doses of rescue opioid (26).

In a trial of tramadol in 241 EMs and 30 PMs for postoperative analgesia, it was reported that $47 \%$ of PMs versus $22 \%$ of EMs were non-responders; $43 \%$ of PMs versus $22 \%$ of EMs needed rescue medication; and a 1.4-fold higher loading dose was used in PMs versus EMs (27). Polymorphisms in drug-metabolizing enzymes and drug transporters contribute to wide and inheritable variability in drug pharmacokinetics, response, and toxicity. One of the less well-studied human cytochrome P450 enzymes is (CYP)2B6, a homologue of the rodent phenobarbital-inducuble CYP2B 
enzymes (28). Contrary to the model polymorphisms of CYP2D6 and CYP2C19, which were discovered by adverse drug reactions, pharmacogenetic study of CYP2B6 was initiated by reverse genetics approaches and subsequent functional and clinical studies (28). The CYP2B6 gene is also highly polymorphic, with at least 50 allelic variants identified (15). The $* 8, * 11$, $* 12$, and *14-*16 variants are associated with either lower CYP2B6 expression or activity (29). Similar to CYP2D6, there are ethnic differences in the frequency of the variant alleles (30). In contrast to CYP2D6, the functional effects of other variants in vivo are not as well characterized and require further investigation especially across ethnic populations (31).

Although CYP2B6 influences (S)-methadone plasma levels, given that $(R)$-methadone is the significant isomer contributing to the muagonist effects of this drug, a major influence of CYP2B6 geneotype on response to treatment is unlikely and has not been shown in this study. Lower plasma levels of methadone in nonresponders, suggesting a higher clearance, higher peak-to-trough ratios, and a shorter elimination halflife, are in agreement with the usual clinical measures taken for such patients, which are to increase methadone dosages and to split the daily dose into multiple divided dosages (32). However, since (S)-methadone may possess activity as an n-methyl-d-aspartate antagonist, the analgesic effects from altered levels of (S)methadone secondary to differing CYP2B6 function for human neuropathic pain may not be completely trivial.

Furthermore, the patient's CYP2B6 status could have other implications. Eap et al (33) performed whole-cell patch-clamp experiments using cells expressing hERG and showed that (S)-methadone blocked the hERG current 3.5-fold more potently than (R)-methadone $\left(\mathrm{IC}_{50} \mathrm{~S}\right.$ [half-maximal inhibitory concentrations] at $37^{\circ} \mathrm{C}: 2$ and $7 \mu \mathrm{M}$ ). As CYP2B6 slow metabolizer (SM) status results in a reduced ability to metabolize (S)-methadone, electrocardiograms, CYP2B6 genotypes, and (R)- and (S)-methadone plasma concentrations were obtained for 179 patients receiving $(\mathrm{R}, \mathrm{S})$-methadone (33). The mean heart-rate-corrected QT (QTC) was higher in CYP2B6 SMs (*6/*6 genotype; $439 \pm 25 \mathrm{~ms} ; \mathrm{n}=11$ ) than in extensive metabolizers (non *6/*6; $421 \pm 25 \mathrm{~ms} ; \mathrm{n}=168 ; P=0.017$ ). CYP2B6 SM status was associated with an increased risk of prolonged QTc (odds ratio $=4.5,95 \%$ confidence interval $=1.2-17.7 ; P=0.03)(33)$.
In contrast to the enzymes leading to various active or inactive opioid metabolites, other enzymes act to conjugate opioids/opioid metabolites in order to make them water-soluble, thereby facilitating their elimination. UGT2B7 is the predominant enzyme that catalyzes morphine glucuronidation (34), and multiple single nucleotide polymorphisms in the promoter region of UGT2B7 have been reported which are of unknown significance (35). The UDP-glucuronosyltransferase (UGT) 2B7 gene encodes for UGT2B7, the primary hepatic enzyme responsible for glucuronidation of morphine, which results in the formation of 2 major metabolites: morphine-6-glucuronide (M6G) and morphine-3-glucuronide (M3G) (34). Functional allelic variants of UGT2B7 may affect hepatic clearance of morphine by altering its enzymatic activity.

Genetic variation in the transcription factor hepatic nuclear factor $1 \alpha$ (HNF-1 $\alpha$ ) may result in up to 10 -fold variability in the expression of uridine diphosphateglucuronosyl transferase 2B7 (UGT2B7) mRNA in human liver biopsies $(36,37)$.

Presence of the UDP-glucuronosyltransferase UGT2B7-840G allele is associated with significantly reduced glucuronidation of morphine and thus contributes to the variability in hepatic clearance of morphine in sickle cell disease $(38,39)$.

\section{Opioid Transporter (OTs)}

Drug transporters are important structural proteins that can influence the absorption, distribution, and elimination of opioids (31). In the gastrointestinal tract and hepatocytes, they have the ability to influence the bioavailability of orally administered opioids by restricting or facilitating intestinal absorption and facilitating presystemic biliary elimination $(40,41)$. In particular, transporter expression at the blood-brain barrier has the potential to significantly influence the clinical efficacy and safety of opioids, whose major site of action lies within the central nervous system (CNS) (31).

Both efflux and uptake carrier systems have been implicated in the transport of opioids (drugs and peptides), with multiple transporters often functioning in concert to facilitate the efficient transfer of substrates across biological membranes. The 2 major families of drug transporters of relevance to opioid pharmacokinetics are the ATP binding cassette (ABC) superfamily of efflux transporters, and the solute carrier (SLC) superfamily of influx transporters (31). 
The $A B C$ superfamily of efflux transporters consists of nearly 50 known human members divided into 7 sub-families. The most characterized of the $A B C$ transporters is the $A B C B 1$ (MDR1, P-glycoprotein (Pgp)) efflux transporter which functions at capillary endothelial cells of the bloodbrain barrier and blood-cerebrospinal fluid barrier (with the $A B C C$ family being less well studied) (42). Opioid induced analgesia is increased and prolonged in mice lacking $P$ glycoprotein (43). Morphine, methadone, loperamide, and fentanyl have all been confirmed as P-gp substrates (44-49). The $A B C B 1$ gene encoding $\mathrm{P}-\mathrm{gp}$ is highly polymorphic, with over 100 SNPs previously identified. The most investigated of the common $A B C B 1$ genetic polymorphisms is the non-synonymous exon 26 SNP, C3435T, which is observed with a frequency of $50-60 \%$ in Caucasians, $40-50 \%$ in Asians, and $10-30 \%$ in Africans (50-53). did find a significant relationship between 3435 genotype and the extent of loperamide miotic effects following P-gp inhibition by quinidine. There is also evidence that the brain distribution of morphine, which is transported by P-gp with less efficiency than loperamide, may be affected by 3435 genotype (54). Pharmacokinetic modelling of morphine in plasma and cerebrospinal fluid revealed a significant association between the homozygous mutant genotype and increased morphine cerebrospinal fluid concentrations (54).

There are numerous SNPs observed in the $A B C B 1$ gene, with significant linkage disequilibrium reported across the $A B C B 1$ gene $(55,56)$. Thus, consideration of the effect of $A B C B 1$ haplotypes, in place of individual SNPs, is more likely to accurately predict P-gp expression and function (57). Investigation of haplotypes formed by the 2677 and 3435 SNPs revealed that subjects carrying the $A B C B 1$ haplotype G2677/T3435 had significantly higher plasma loperamide concentrations than non-carriers (53).

Genetic variation in the multidrug-resistance gene MDR-1 (which encodes for P-glycoprotein, a membrane-bound drug transporter that regulates transfer of opioids across the bloodbrain barrier by actively pumping opioids out of the CNS) may account for the genetic variability in P-glycoprotein activity $(37,58)$. The mutation resulting in the G2677T/A genotype of P-glycoprotein has been demonstrated to alter drug levels (59) and drug-induced side effects (60).

Campa et al (61) hypothesized that patients having both good efflux pump functionality ( $A B C B 1$ ) $M D R 1$ homozygous $C / C$ ) and a defective morphine re- ceptor (OPRM1 homozygous G/G) would be the worst responders to pain relief treatment. By contrast, patients with an ineffective efflux pump ( $A B C B 1 / M D R 1$ homozygous $\mathrm{T} / \mathrm{T}$ ) and a functional receptor (OPRM1 homozygous A/A) were expected to be the best responders (61). Pain relief variability was significantly ( $p<0.0001)$ associated with both polymorphisms (61). Combining the extreme genotypes of both genes, the association between patient polymorphism and pain relief improved $(p<0.00001)$, allowing the detection of 3 groups: strong responders, responders, and nonresponders, with sensitivity close to $100 \%$ and specificity more than $70 \%(61)$.

Additionally, methadone is a substrate for the $\mathrm{P}$ glycoprotein transporter, encoded by the $A B C B 1$ gene, which regulates $C N S$ exposure. In a retrospective study, Coller and colleagues (62) found that $A B C B 1$ genetic variability appeared to influence daily methadone dose requirements, such that subjects carrying 2 copies of the wild-type haplotype required higher doses compared with those with 1 copy and those with no copies $(98.3 \pm 10.4,58.6 \pm 20.9$, and $55.4 \pm 26.1 \mathrm{mg} / \mathrm{d}$, respectively; $p=.029$ ) (62).

The organic anion transporting polypeptide family consists of 9 human isoforms, of which 2 SLCO1A2 (organic anion transporting polypeptide 1A2) and SLCO1B3 (organic anion transporting polypeptide 1B3 organic anion transporting polypeptide-8) have been implicated in opioid transport (31). The role of genetic polymorphisms in transporters of the ABCC and SLCO families on opioid actions is unclear (31).

\section{Pharmacodynamic Variability}

\section{Opioid Receptors (ORs)}

Mu, kappa, and delta opioid receptors (encoded by the OPRM1, OPRK1, and OPRD1 genes, respectively) may all have polymorphisms. Several polymorphic variants of the human OPRM1 gene have been described (63-66), including variants that alter amino acid sequence of the receptor as well as properties of receptor function, studied using in vitro expression systems $(65,67-69)$. There is evidence to suggest that muopioid receptor mutations may contribute to inter-individual variability of the clinical effects of opioids (70).

Splice variants of the mu opioid receptor (MOR1A, MOR-1B, MOR-1C, etc.) have been identified as well as other variants involving alternative splicing at the $3^{\prime}$ end or the $5^{\prime}$ end of the mRNA (71). The variants may utilize a different promoter and possess differ- 
ent characteristics/locations/functions. Some variants may respond to morphine but not to morphine-6glucuronide (M6G) and vice versa (71). MOR-1 mRNA, the major MOR transcript, possesses a long 3 ' untranslated region ( $3^{\prime} U T R$ ) in both mouse and human species (72). The sequence of the MOR-1 3'UTR, especially that of its $3^{\prime}$ end region, is conserved between mice and humans (72). The CXBK mouse strain, known as a MOR-deficient strain, possesses a decreased amount of MOR-1 mRNA containing an abnormally long MOR1 3'UTR with a long nucleotide insertion (72). This insert might disrupt the stability of the MOR-1 mRNA or might reduce the transcription of the MOR-1 mRNA by separating the transcription factor-binding motifs in the $3^{\prime}$ non-coding region of the MOR gene, thereby decreasing MOR-1 mRNA expression and attenuating morphine-induced analgesia in CXBK mice (72).

Investigators have identified more than 100 polymorphisms in the human MOR gene (Oprm), with some variants exhibiting altered binding affinities to different opioids $(37,73,74)$. The best-known polymorphism in the Oprm is the A118G nucleotide substitution, which codes for the amino acid change of asparagine to aspartic acid. It is unclear whether genetic variation in various polymorphisms contributes to variation in the effects of different opioids.

The A118G variant of the human mu opioid receptor gene (OPRM1) is in the coding region of the first exon and is the single nucleotide polymorphism (SNP) with the highest overall allelic frequency of any OPRM1 coding region variant reported, although its heterozygosity varies widely across populations; from $1 \%$ to $2 \%$ frequencies of the minor (118G) allele reported in African Americans to up to $50 \%$ in Japanese $(65,75-79)$. This SNP (a nucleotide substitution at position 118 [A118G]) encodes an amino acid substitution of asparagine to aspartic acid at position 40 in the extracellular amino-terminus which removes 1 of 5 potential $\mathrm{N}$-glycosylation sites of the receptor. The single nucelotide polymorphism A118G alters functional properties of the human mu opioid receptor (80).

Subjects carrying 1 or 2 copies of the variant G allele were found to have a reduced response to morphine treatment and a reduced analgesic response to alfentanil (81-83) and morphine-6-glucuronide (84). Chou et al $(85,86)$ studied patients who underwent total knee arthroplasty and abdominal total hysterectomy, and they observed that G/G homozygotes have a poorer response to morphine for postoperative pain control than A/A homozygotes or heterozygotes.
Klepstad et al (87) showed that cancer patients homozygous for the $\mathrm{G}$ allele required higher doses of morphine to relieve pain.

Lötsch and colleagues (88) investigated the central nervous effects of levomethadone by means of measuring pupil size in a random sample of 51 healthy volunteers for 9 hours after oral administration of $0.075 \mathrm{mg} / \mathrm{kg}$ levomethadone. Lötsch et al (88) concluded among polymorphisms in OPRM1, $A B C B 1$, and CYP genes previously associated with functional consequences in a different context, the most important pharmacogentic factor modulating the short-term effects of levomethadone is the polymorphism (OPRM1 $118 \mathrm{~A}>\mathrm{G}$ ) affecting muopioid receptors (88).

Ross and colleagues (2005) (89) compared "opioid switchers" who did not tolerate morphine with "controls" who responded to morphine; their study revealed significant differences in the genotype of the signal transducer and activator of the transcription 6 (STAT-6) gene between "switchers" and "controls." STAT-6 recognition sites may exist in the Oprm gene. STAT-6 may interact with Oprm, altering Oprm expression and affecting different opioid responses (89).

Another phenomenon which may contribute to the clinical variability of opioids is that of opioid receptor heterodimerization. Opioid receptors belong to the G-protein-coupled receptor (GPCR) superfamily. GPCRs can form homo- (2 identical protomer partners) and hetero- (2 different protomer partners) dimers. An important discovery has been the observation that a pair of interacting GPCRs can have distinct pharmacological properties (90). Hence, dimerization could be seen as a way for an organism to increase the functional variety of GPCRs (90). It is likely that repertoires of heterodimers in different tissues are unique and that a specific dimer pair could represent a target potentially found in fewer tissues (90).

In the opioid receptor family, $\delta$ opioid receptors have been shown to interact with both $\kappa$ and $\mu$ opioid receptors to form heterodimers, and this leads to altered pharmacological properties $(91,92)$. In the case of interactions between $\kappa$ and $\delta$ receptors, the resultant $\kappa-\delta$ heterodimers were found to have greatly reduced affinities for highly selective $\kappa$ or $\delta$ receptor ligands (91). Studies with $\mu-\delta$ heterodimers also demonstrated decreased binding affinity to selective synthetic agonists (93). Moreover, potentiation of a $\mu$ opioid receptor agonist binding by a $\delta$ antagonist observed in vitro leads to increased antinociceptive responses using a classical analgesia test (94). 
GPCRs are natural allosteric proteins. The presence of GCPRs in dimeric or oligomer complexes enables allosteric interactions between the protomer partners within the dimer. In the case of mu-delta heterodimers, presence of a muopioid receptor agonists leads to a normal/expected response that would be further potentiated if a delta opioid receptor agonist were coadministered with a muopioid receptor agonist (e.g. an exaggerated inositol triphosphate (IP3)-induced intracellular release of calcium).

\section{Molecules in Opioid Signaling Pathways (Opioid Signalers [OSs])}

Studies using gene knockout mice have suggested that a number of receptors, channels, transporters, neurotransmitters, and signal transduction molecules are implicated in the analgesic and adverse effects of opioids, especially morphine (95). Girk2 gene (Kcnj6) knockout and Girk3 gene (Kcnj9) knockout mice display hyperalgesia and reduced analgesic efficacy of morphine (96). Weaver mutant mice, which harbor a point mutation in the Girk2 pore domain, also exhibit decreased morphine-induced analgesia (97). These data suggest that Girk2 and Girk3 subunits may be largely responsible for morphine-induced analgesia. R-type voltage-dependent calcium channel (Cav2.3) gene (Cacna1e) knockout mice also exhibit altered analgesia and tolerance induced by morphine $(95,98)$.

Mice with gene knockout of the $\alpha 2 \mathrm{~A}$ adrenergic receptor, muscarinic acetylcholine receptor 1, dopamine receptor 2, histamine receptors $\mathrm{H} 1$ and $\mathrm{H} 2$, prolactin releasing peptide receptor, norepinephrine transporter, arachidonate 12-lipooxygenase, $\beta 2$ arrestin, and phospholipase $C \beta 3$, in addition to melanocortin-1 receptor spontaneous mutant mice, show enhanced analgesia induced by opioids (95). In contrast, adenosine A1 receptor, cholecystokinin $B$ receptor, nociceptin receptor, dopamine, dopamine $\beta$-hydroxylase, adenylate cyclase 5, tamalin, phospholipase $C \beta 1$, interleukin 6, and $\operatorname{Lmx} 1 \beta$ deficient mice exhibit reduced opioid-induced analgesia (95).

Catechol-O-methyl transferase (COMT) is the enzyme which metabolizes dopamine, epinephrine, and norepinephrine to methoxytyramine, metanephrine, and normetanephrine, respectively. The A472G (Val158Met, rs4680) SNP is the most common SNP in the COMT gene. The regional $\mu$ opioid system response to pain is diminished in healthy volunteers with the Met/Met genotype compared to those with the Val/ Met genotype (99). Caucasian cancer patients with the Val/Val genotype require more morphine (155 \pm 160 $\mathrm{mg} / \mathrm{h})$ compared to Val/Met $(117 \pm 100 \mathrm{mg} / \mathrm{h})$ and Met/ Met genotypes (95 $\pm 99 \mathrm{mg} / \mathrm{h})$ (100). Similarly, carriers of the $\mathrm{Val} / \mathrm{Val}$ and $\mathrm{Val} / \mathrm{Met}$ genotype require $63 \%$ and $23 \%$, respectively, higher doses of morphine compared to carriers of the Met/Met genotype (101).

Ross et al (2005) (89) found a significant difference in genotype and allelic frequency for the T8622C polymorphism in the $\beta$-arrestin- 2 gene, which encodes for $\beta$ - arrestin (an intracellular protein involved in regulating MOR phosphorylation, desensitization, and internalization); this variation is of unclear clinical significance.

\section{SUMMARY}

It has been clinically acknowledged for many years that there exists significant variability in opioid responsiveness. The multiple factors which may be involved in this variability continue to be elucidated. As this knowledge matures along with a greater understanding of the specific importance of each of these factors in terms of their effects on opioid-induced analgesia for humans in pain, it is hoped that clinicians may be better equipped to choose the optimal opioid and opioid dose to tailor analgesic regimens or to make informed decisions regarding opioid rotation strategies in efforts to achieve the best individual patient outcomes. 


\section{References}

1. Mather LE, Glynn CJ. The minimum effective analgetic blood concentration of pethidine in patients with intractable pain. $\mathrm{Br}$ J Clin Pharmacol 1982; 14:385-390.

2. Glass PSA, Schafer SI, Reves JG. Intravenous drug delivery systems. In: Miller RD (ed) Miller's Anesthesia, 5th ed Elsevier/Churchill Livingstone, Philadelphia, PA. 2000; pp377-411.

3. Jones AK, Watabe H, Cunningham VJ, Jones T. Cerebral decreases in opioid receptor binding in patients with central neuropathic pain measured by $[11 \mathrm{C}] \mathrm{di}-$ prenorphine binding and PET. Eur J Pain 2004; 8:479-485.

4. Maarrawi J, Peyron R, Mertens P, Costes N, Magnin M, Sindou M, Laurent B, Garcia-Larrea L. Differential brain opioid receptor availability in central and peripheral neuropathic pain. Pain 2007; 127: 183-194.

5. Narita M, Kaneko C, Miyoshi K, Naguma Y, Kuzumaki N, Nakajima M, Nanjo K, Matsuzawa K, Yamazaki M, Suzuki T. Neuropsychopharmacology 2006; 31: 739-750.

6. Vaughan $\mathrm{CW}$, Ingram SL, Connor MA, Christie MJ. How opioids inhibit GABAmediated neuratransmission. Nature 1997; 390:611-614.

7. Vaughan CW, McGregor IS, Christis MJ. Cannabinoid receptor activation inhibits GABAergic neurotransmission in rostral ventromedial medulla neurons in vitro. BrJ Pharmacol 1999; 127:935-940.

8. de Cid R, Ronseca F, Gratacòs M, Gutierrez F, Martin-Santos R, Estivill X, Torrens $M$. BDNF variability in opioid addicts and response to methadone treatment: Preliminary findings. Genes Brain Behav 2007; in print.

9. Oertel BG, Preibisch C, Wallenhorst T, Hummel T, Geisslinger G, Lanfermann $\mathrm{H}$, Lötsch J. Differential opioid action on sensory and affective cerebral pain processing. Clin Pharmacol Ther 2007; in press.

10. Hough LB, Nalwalk JW, Phillips JG, Kern B, Shan Z, Wentland MP, de Esch IJP, Jansse E, Barr T, Stadel R. CC12, a highaffinity ligand for $[3 \mathrm{H}]$ cimetidine binding is an important antagonist. Neuropharm 2007; 52:1244-1255.

11. Eichelbaum M, Evert B. Influence of pharmacogenetics on drug disposition and response. Clin Exp Pharmacol Physiol 1996; 23:983-985.
12. Roses A. Pharmacogenetics and future drug development and delivery. Lancet 2000; 355:1358-1361.

13. Sachse C, Brockmoller J, Bauer S, Roots I. Cytochrome P450 2D6 variants in a Caucasian population: Allele frequencies and phenotypic consequences. Am J Hum Genet 1997; 60:284-295.

14. Eckhardt K, Li S, Ammon S, Schanzle G, Mikus G, Eichelbaum M. Same incidence of adverse drug events after codeine administration irrespective of the genetically determined differences in morphine formation. Pain 1998; 76:2733.

15. Sim S, Ingelman-Sundberg M, Daly AK, Nebert DW. Home page of the Human Cytochrome P450 (CYP) Allele Nomenclature, www.cypalleles.ki.se/ (2006).

16. Zanger UM, Raimundo S, Eichelbaum M. Cytochrome P450 2D6: Overview and update on pharmacology, genetics, biochemistry. Naunyn-Schmiedeberg's Arch Pharmacol 2004; 369:23-37.

17. Wang G, Zhang H, He F, Fang X. Effect of the CYP2D6*10 C188T polymorphism on postoperative tramadol analgesia in a Chinese population. Eur J Clin Pharmacol 2006; 62:927-931.

18. Løvlie R, Daly AK, Matre GE, Molven A, Steen VM. Polymorphisms in CYP2D6 duplication-negative individuals with the ultrarapid metabolizer phenotype: A role for the $\mathrm{CYP}_{2} \mathrm{D}^{*}{ }^{*} 35$ allele in ultrarapid metabolism? Pharmacogenetics 2001; 11:45-55.

19. Bertilsson L, Dahl ML, Ekqvist B, Jerling $M$, Lierena A. Genetic regulation of the disposition of psychotropic drugs. In: Meltzer HY, Nerozzi D (eds) Current Practices and Future Developments in the Pharmacotherapy of Mental Disorders Elsevier, Amsterdam,1991; pp7380.

20. Otton SV, Schadel M, Cheung SW, Kaplan HL, Busto UE, Sellers EM. CYP2D6 phenotype determines the metabolic conversion of hydrocodone to hydromorphone. Clin Pharmacol Ther 1993; 54:463-472.

21. Kirkwood LC, Nation RL, Somogyi AA. Characterization of the human cytochrome $\mathrm{P} 450$ enzymes involved in the metabolism of dihydrocodeine. Br J Clin Pharmacol 1997; 44:549-555.

22. Subrahmanyam $V$, Renwick $A B$, Walters DG, Young PJ, Price RJ, Tonelli AP, Lake BG. Identification of cytochrome
P-450 isoforms responsible for cis-tramadol metabolism in human liver microsomes. Drug Metab Dispos 2001; 29:1146-1155.

23. Lalovic B, Phillips B, Risler LL, Howald W, Shen DD. Quantitative contribution of $\mathrm{CYP}_{2} \mathrm{D} 6$ and $\mathrm{CYP}_{3} \mathrm{~A}$ to oxycodone metabolism in human liver and intestinal microsomes. Drug Metab Dispos 2004; 32:447-454.

24. Lötsch J, Skarke C, Liefhold J, Geisslinger G. Genetic predictors of the clinical response to opioid analgesics: Clinical utility and future perspectives. Clin Pharmacokinet 2004; 43:983-1013.

25. Persson K, Sjöström S, Sigurdardottir I, Molnár V, Hammarlund-Udenaes M, Rane A. Patient-controlled analgesia (PCA) with codeine for postoperative pain relief in ten extensive metabolisers and one poor metaboliser of dextromethorphan. $\mathrm{Br} / \mathrm{Clin}$ Pharmacol 1995; 39:182-186.

26. Maddocks I, Somogyi A, Abbott F, Hayball P, Parker D. Attenuation of morphine-induced delirium in palliative care by substitution with infusion of oxycodone. I Pain Symptom Manage 1996; 12:182-189.

27. Stamer UM, Lehnen K, Höthker F, Bayerer B, Wolf S, Hoeft A, Stuber F. Impact of CYP2D6 genotype on postoperative tramadol analgesia. Pain 2003; 105: 231-238.

28. Zanger UM, Klein K, Saussele T, Blievernicht J, Hoffmann MH, Schwab M. Polymorphic CYP2B6: Molecular mechanisms and emerging clinical significance. Pharmacogenics 2007; 8:743759.

29. Lang T, Klein K, Richter T, Zibat A, Kerb $R$, Eichelbaum M, Schwab M, Zanger UM. Multiple novel nonsynonymous CYP2B6 gene polymorphisms in Caucasians: Demonstration of phenotypic null alleles. J Pharmacol Exp Ther 2004; 311:34-43.

30. Guan S, Huang M, Li X, Chen X, Chan $E$, Zhou SF. Intra- and inter-ethnic differences in the allele frequencies of cytochrome P450 2B6 gene in Chinese. Pharm Res 2006; 23:1983-1990.

31. Somogyi AA, Barratt DT, Coller JK. Pharmacogenetics of opioids. Clinical Pharmacoly Ther 2007; 81:429-444.

32. Crettol S, Dégion JJ, Besson J, Croquette-Krokkar M, Gothuey I, Hämmig $\mathrm{R}$, Monnat $\mathrm{M}$, Hüttemann $\mathrm{H}$, Baumann 
P, Eap CB. Methadone enantiomer plasma levels, $\mathrm{CYP}_{2} \mathrm{~B} 6, \mathrm{CYP}_{2} \mathrm{C}_{1}$, and $\mathrm{CYP}_{2} \mathrm{C}_{9}$ genotypes, and response to treatment. Clin Pharmacol Ther 2005; 78:593-604.

33. Eap CB, Crettol S, Rougier JS, Schläpfer J, Sintra Grilo L, Déglon JJ, Besson J, Croquette-Krokar M, Carrupt PA, Abriel $H$. Stereoselective block of hERG channel by (S)-methadone and QT interval prolongation in $\mathrm{CYP}_{2} \mathrm{~B} 6$ slow metabolizers. Clin Pharmaol Ther 2007; 81: 719-728.

34. Coffman BL, Rios GR, King CD, Tephly TR. Human UGT2B7 catalyzes morphine glucuronidation. Drug Metab Dispos 1997; 25:1-4.

35. Duguay Y, Báár C, Skorpen F, Guillemette C. A novel functional polymorphism in the uridine diphosphate-glucuronosyltransferase $2 \mathrm{~B} 7$ promoter with significant impact on promoter activity. Clin Pharmacol Ther 2004; 75:223233.

36. Toide K, Takahashi Y, Yamazaki H, Terauchi Y, Fujii T, Parkinson A, Kamataki T. Hepatocyte nuclear factor-1 alpha is a causal factor responsible for interindividual differences in expression of UDP-glucuronosyltransferase 2B7 mRNA in human livers. Drug Metab Dispos 2002; 30:613-615.

37. Ross JR, Riley J, Quigley C, Welsh KI. Clinical pharmacology and pharmacotherapy of opioid switching in cancer patients. Oncologist 2006; 11:765-773.

38. Darbari DS, Minniti CP, Rana S, van den Anker J. Pharmacogenetics of morphine: Potential implications in sickle cell disease. Am J Hematol 2007; in press.

39. Darbari DS, van Schaik RH, Capparelli EV, Rana S, McCarter R, van den Anker J. UGT2B7 promoter variant $-840 \mathrm{G} \cdots \cdot \mathrm{A}$ contributes to the variability in hepatic clearance of morphine in patients with sickle cell disease. Am J Hematol 2007; in press.

40. Dietrich CG, Geier A, Oude Elferink RP. ABC of oral bioavailability: Transporters as gatekeepers in the gut. Gut 2003; 52:1788-1795.

41. Chan LMS, Lowes S, Hirst BH. The ABCs of drug transport in intestine and liver: Efflux proteins limiting drug absorption and bioavailability. Eur J Pharm Sci 2004; 21,25-51.

42. Fromm MF. Importance of P-glycoprotein and blood-tissue barriers. Trends Pharmacol Sci 2004; 25:423-429.
43. Thompson SJ, Koszdin K, Bernards CM. Opiate-induced analgesia is in creased and prolonged in mice lacking P-glycoprotein. Anesthesiology 2000; 92:1392-1399.

44. Sadeque AJ, Wandel C, He H, Shah S, Wood AJ. Increased drug delivery to the brain by P-glycoprotein inhibition. Clin Pharmacol Ther 2000; 68:231-237.

45. Kharasch ED, Hoffer C, Whittington D, Sheffels P. Role of P-glycoprotein in the intestinal absorption and clinical effects of morphine. Clin Pharmacol Ther 2003; 74:543-554.

46. Drewe J, Ball HA, Beglinger C, Peng B, Kemmier A, Schächinger H, Haefeli WE. Effect of p-glycoprotein modulation on the clinical pharmacokinetics and adverse effects of morphine. $\mathrm{Br} / \mathrm{Clin}$ Pharmacol 2000; 50:237-246.

47. Skarke C, Jarrar M, Erb K, Schmidt H, Geisslinger G, Lötsch J. Respiratory and miotic effects of morphine in healthy volunteers when P-glycoprotein is blocked by quinidine. Clin Pharmacol Ther 2003; 74:303-311.

48. Kharasch ED, Hoffer C, Altuntas TG, Whittington D. Quinidine as a probe for the role of p-glycoprotein in the intestinal absorption and clinical effects of fentanyl. J Clin Pharmacol 2004; 44:224-233.

49. Kharasch ED, Hoffer C, Whittington D. The effect of quinidine, used as a probe for the involvement of P-glycoprotein, on the intestinal absorption and pharmacodynamics of methadone. Br J Clin Pharmacol 2004; 57:600-610.

50. Kerb R. Implications of genetic polymorphisms in drug transporters for pharmacotherapy. Cancer Lett 2006; 234:4-33

51. Cascorbi I. Role of pharmacogenetics of ATP-binding cassette transporters in the pharmacokinetics of drugs. Pharmacol Ther 2006; 112:457-473.

52. Ameyaw MM, Regateiro F, Li T, Liu X, Tariq M, Mobarek A, Thornton N, Folayan GO, Githang's J, Indalo A, Ofori-Adjei D, Price-Evans DA, McLeod HL. MDR1 pharmacogenetics: Frequency of the C 3435 T mutation in exon 26 is significantly influenced by ethnicity. Pharmacogenetics 2001; 11:217-221.

53. Skarke C, Jarrar M, Schmidt H, Kauert G, Langer M, Geisslinger G, Lötsch J. Effects of $A B C B 1$ (multidrug resistance transporter) gene mutations on disposition and central nervous effects of loperamide in healthy volunteers. Pharmacogenetics 2003; 13:651-660.
54. Meineke I, Freudenthaler S, Hofmann U, Schaeffeler E, Mikus G, Schwab M, Prange HW, Gleiter $\mathrm{CH}$, Brockmöller J. Pharmacokinetic modelling of morphine, morphine-3-glucuronide and morphine-6-glucuronide in plasma and cerebrospinal fluid of neurosurgical patients after short-term infusion of morphine. Br J Clin Pharmacol 2002; 54:592-603.

55. Kroetz DL, Pauli-Magnus C, Hodges LM, Huang CC, Kawamoto M, Johns SJ, Stryke D, Ferrin TE, DeYoung J, Taylor T, Carlson EJ, Herskowitz I, Giacomini KM, Clark AG, Pharmacogentics of membrane transporters investigators. Sequence diversity and haplotype structure in the human $A B C B 1$ (MDR1, multidrug resistance transporter) gene. Pharmacogenetics 2003; 13:481-494.

56. Kim RB. MDR1 single nucleotide polymorphisms: Multiplicity of haplotypes and functional consequences. Pharmacogenetics 2002; 12:425-427.

57. Johne A, Köpke K, Gerloff T, Mai I, Rietbrock S, Meisel C, Hoffmeyer S, Kerb R, Fromm MF, Brinkman U, Eichelbaum M, Brockmöller J, Cascorbi I, Roots I. Modulation of steady-state kinetics of digoxin by haplotypes of the P-glycoprotein MDR1 gene. Clin Pharmacol Ther 2002; 72:584-594.

58. Marzolini C, Paus E, Buclin T, Kim RB. Polymorphisms in human MDR1 (P-glycoprotein): Recent advances and clinical relevance. Clin Pharmacol Ther 2004; 75:13-33.

59. Kim RB, Leake BF, Choo EF, Dresser GK, Kubba SV, Shcwartz UI, Taylor A, Xie HG, McKinsey J, Zhou S, Lan LB, Scheutz JD, Schuetz EG, Wilkinson GR. Identification of functionally variant MDR1 alleles among European Americans and Africans Americans. Clin Pharmacol Ther 2001; 70:189-199.

6o. Yamauchi A, leiri I, Kataoka Y, Tanabe M, Nishizaki T, Oishi R, Higuchi S, Otsubo K, Sugimachi K. Neurotoxicity induced by tacrolimus after liver transplantation: Relation to genetic polymorphisms of the ABCBI (MDR1) gene. Transplantation 2002; 74:571-572.

61. Campa D, Gioia A, Tomei A, Poli P, Barale R. Association of $A B C B_{1} / M D R 1$ and OPRM1 gene polymorphisms with morphine pain relief. Clin Pharm Ther 2007, in print.

62. Coller JK, Barratt DT, Dahlen K, Loennechen $M H$, Somogyi $A A$. ABCB1 genetic variability and methadone dosage requirements in opioid-dependent 
individuals. Clin Pharmacol Ther 2006; 80:682-690.

63. Bergen AW, Kokoszka J, Peterson R, Long JC, Virkkunen M, Linnoila M, Goldman D. Mu opioid receptor gene variants: Lack of association with alcohol dependence. Mol Psychiatry 1997; 2: 490-494.

64. Berrettini WH, Hoehe MR, Ferraro TN, DeMaria PA, Gottheil E. Human mu opioid receptor gene polymorphisms and vulnerability to substance abuse. Addict Biol 1997; 2:303-308.

65. Bond C, LaForge KS, Tian M, Melia D, Zhang S, Borg L, Gong J, Schluger J, Strong JA, Leal SM, Tischfield JA, Kreek MJ, Yu L. Single nucleotide polymorphism in the human mu opioid receptor gene alters beta-endorphin binding and activity: Possible implications for opiate addiction. Proc Natl Acad Sci USA 1998; 95:9608-9613.

66. Hoehe MR, Kopke K, Wendel B, Rohde K, Flachmeier C, Kidd KK, Berrettini WH, Church GM. Sequence variability and candidate gene analysis in complex disease: Association of mu opioid receptor gene variation with substance dependence. Hum Mol Genet 2000; 9:2895-2908.

67. Koch T, Kroslak T, Averbeck M, Mayer P, Schröder H, Raulf E, Höllt V. Allelic variation S268P of the human mu-opioid receptor affects both desensitization and $\mathrm{G}$ protein coupling. Mol Pharmacol 2000; 58:328-334.

68. Befort K, Filliol D, Decaillot FM, Gavériaux-Ruff C, Hoehe MR, Kieffer BL. A single nucleotide polymorphic mutation in the human mu-opioid receptor severely impairs receptor signaling. I Biol Chem 2001; 276:3130-3137.

69. Margas W, Zubkoff I, Schuler HG, Janicki PK, Ruiz-Velasco V. Modulation of Ca2+ channels by heterologously expressed wild-type and mutant human $\mu$-opioid receptors (hMOR) containing the $\mathrm{A} 118 \mathrm{G}$ single nucleotide polymorphism. J Neurophysiol 2007; 97:1058-1067.

70. Lötsch J, Geisslinger G. Are mu-opioid receptor polymorphisms important for clinical opioid therapy? Trends $\mathrm{Mol}$ Med 2005; 11:82-89.

71. Pasternak GW. Molecular biology of opioid analgesia. J Pain Sympt Manag 2005; 29:2-9.

72. Kasai S, Han W, Ide S, Hata H, Takamatsu Y, Yamamoto H, Uhl GR, Sora I, Ikeda $\mathrm{K}$. Involvment of the $3^{\prime}$ non-coding region of the mu opioid receptor gene in morphine-induced analgesia. Psychia- try Clin Neurosci 2006; 60:Suppl 1:S1117.

73. Surratt CK, Johnson PS, Moriwaki $A$, Seidleck BK, Blaschak CJ, Wang JB, Uhl GR. Mu opiate receptor. Charged transmembrane domain amino acids are critical for agonist recognition and intrinsic activity. J Biol Chem 1994; 269:20548-20553.

74. Pil J, Tytgat J. The role of the hydrophilic Asn23o residue of the mu-opioid receptor in the potency of various opioid agonists. $\mathrm{Br} /$ Pharamacol 2001; 134:496-506.

75. Gelernter J, Kranzler H, Cubells J. Genetics of two mu opioid receptor gene (OPRM1) exon I polymorphisms: Population studies and allele frequencies in alcohol- and drug-dependent subjects. Mol Psychiatry 1999; 4:476-483.

76. Szeto CY, Tang NL, Lee DT, Stadlin A. Association between mu opioid receptor gene polymorphisms and Chinese heroin addicts. Neuroreport 2001; 12:1103-1106.

77. Tan EC, Chong SA, Mahendran R, Tan $\mathrm{CH}$, Teo YY. Mu opioid receptor gene polymorphism and neuroleptic-induced tardive dyskinesia in patients with schizophrenia. Schizophr Res 2003; 65:61-63.

78. Bart G, Heilig M, LaForge KS, Pollak L, Leal SM, Ott J, Kreek MJ. Substantial attributable risk related to a functional mu-opioid receptor gene polymorphism in association with heroin addiction in Central Sweden. Mol Psychiatry 2004; 9:547-549.

79. Kim SG, Kim CM, Kang DH, Kim YJ, Byun WT, Kim SY, Park JM, Kim MJ, Oslin DW. Association of functional opioid receptor genotypes with alcohol dependence in Koreans. Alcohol Clin Exp Res 2004; 28:986-990.

8o. Korslak T, LaForge KS, Gianotte RJ, Ho A, Nielsen DA, Kreek MJ. The single nucelotide polymorphism A118G alters functional properties of the human mu opioid receptor. I Neurochem 2007; 103:77-87.

81. Romberg RR, Olofsen E, Bijl H, Taschner PE, Teppema LJ, Sarton EY, van Kleef JW, Dahan A. Polymorphism of mu-opioid receptor gene (OPRM1:C.118A $>\mathrm{G}$ ) does not protect against opioid-induced respiratory depression despite reduced analgesic response. Anesthesiology 2005; 102:522-530.

82. Oertel BG, Schmidt R, Schneider A, Geisslinger G, Lotsch J. The mu-opioid receptor gene polymorphism $118 \mathrm{~A}>\mathrm{G}$ depletes alfentanil-induced analgesia and protects against respiratory depression in homozygous carriers. Pharmacogenet Genomics 2006; 16:625636.

83. Lotsch J, Geisslinger G. Relevance of frequent [mu]-opioid receptor polymorphisms for opioid activity in healthy volunteers. Pharmacogenomics / 2006; 6:200-210.

84. Skarke C, Darimont J, Schmidt H, Geisslinger G, Lotsch J. Analgesic effects of morphine and morphine-6glucuronide in a transcutaneous electrical pain model in healthy volunteers. Clin Pharmacol Ther 2003; 73:107-121.

85. Chou WY, Yang LC, Lu HF, Ko JY, Wang $\mathrm{CH}$, Lin SH, Lee TH, Concejero A, Hsu CJ. Association of mu-opioid receptor gene polymorphism (A118G) with variations in morphine consumption for analgesia after total knee arthroplasty. Acta Anaesthesiol Scand 2006; 50:787-792.

86. Chou WY, Wang CH, Liu PH, Liu CC, Tseng CC, Jawan B. Human opioid receptor A118G polymorphism affects intravenous patient-controlled analgesia morphine consumption after total abdominal hysterectomy. Anesthesiology 2006; 105:334-337.

87. Klepstad P, Rakvåg TT, Kaasa S, Holthe M, Dale O, Borchgrevink PC, Baar C, Vikan T, Krokan HE, Skorpen F. The 118 $\mathrm{A}>\mathrm{G}$ polymorphism in the human micro-opioid receptor gene may increase morphine requirements in patients with pain caused by malignant disease. Acta Anaesthesiol. Scand 2004; 48;1232-1239.

88. Lötsch J, Skarke C, Wieting J, Oertel BG, Schmidt H, Brockmöller J, Geisslinger G. Modulation of the central nervous effects of levomethadone by genetic polymorphisms potentially affecting its metabolism, distribution, and drug action. Clin Pharmacol Ther 2006; 79:7289.

89. Ross JR, Rutter D, Welsh K, Joel SP, Goller K, Wells AU, Du Bois R, Riley J. Clinical response to morphine in cancer patients and genetic variation in candidate genes. Pharmacogenomics 2005;5:324-336.

90. Gupta A, Décaillot FM, Devi LA. Targeting opioid receptor heterodimers: strategies for screening and drug development. AAPS Journal 2006; 8: E153-E159.

91. Jordan BA, Devi LA. G-protein coupled receptor heterodimerization modulates receptor function. Nature 1999; 399:697-700. 
92. Gomes I, Jordan BA, Gupta A, Trapaidze N, Nagy V, Devi LA. Heterodimerization of $\mathrm{mu}$ and delta opioid receptors: $\mathrm{A}$ role in opiate synergy. J Neurosci 2000; 20:RC110.

93. George SR, Fan T, Xie Z, Tse R, Tam V, Varghese G, O'Dowd BF. Oligomerization of mu and delta opioid receptors: Generation of novel functional properties. J Biol Chem 2000; 275: 26128-26135.

94. Gomes I, Gupta A, Filipovska J, Szeto HH, Pintar JE, Devi LA A role for heterodimerization of $\mu$ and $\delta$ opiate receptors in enhancing morphine analgesia. Proc Natl Acad Sci USA 2004; 101:5135-5139.

95. Kasai S, Hayashida M, Sora I, Ikeda K. Candidate gene polymorphisms predicting individual sensitivity to opioids. Naunyn-Schmiedeberg's Arch Pharmacol 2007; in press.
96. Marker CL, Cintora SC, Roman MI, Stoffel M, Wickman K. Hyperalgesia and blunted morphine analgesia in $\mathrm{G}$ protein-gated potassium channel subunit knockout mice. Neuroreport 2002; 13:2509-2513.

97. Ikeda K, Kobayashi T, Kumanishi T, Niki $\mathrm{H}$, Yano R. Involvement of G-proteinactivated inwardly rectifying $\mathrm{K}$ (GIRK) channels in opioid-induced analgesia. Neurosci Res 2000; 38:113-116.

98. Yokoyama K, Kurihara T, Saegusa H, Zong S, Makita K, Tanabe T. Blocking the R-type (Cav2.3) Ca2+ channel enhanced morphine analgesia and reduced morphine tolerance. Eur J Neurosci 2004; 20:3516-3519.

99. Zubieta JK, Heitzeg MM, Smith YR, Buel- ler JA, Xu K, Xu Y, Koeppe RA, Stohler CS, Goldman D. COMT val158met genotype affects $\mu$-opioid neurotransmitter responses to a pain stressor. Science 2003; 299:1240-1243.

100. Rakvåg TT, Klepstad P, Baar C, Kvam TM, Dale O, Kaasa S, Krokan HE, Skorpen F. The Val158Met polymorphism of the human catechol-0-methyltransferase (COMT) gene may influence morphine requirements in cancer pain patients. Pain 2005; 116:73-78.

101. Reyes-Gibby CC, Shete S, Rakvåg T, Bhat SV, Skorpen F, Bruera E, Kaasa S, Klepstad P. Exploring joint effects of genes and the clinical efficacy of morphine for cancer pain: OPRM 1 and COMT gene. Pain 2007; 130:25-30. 